\title{
SWOT Analysis for Developing Dry Ports in Togo
}

\author{
Degbe Sewodo Augustin ${ }^{*}$, Dassanou Latre Akossiwa ${ }^{2}$ \\ ${ }^{1}$ School of Economics \& Management, Shanghai Maritime University, Shanghai, China \\ ${ }^{2}$ College of Transport \& Communications, Shanghai Maritime University, Shanghai, China \\ Email: ^deseaucom@yahoo.com, 13816261387@163.com
}

How to cite this paper: Augustin, D.S. and Akossiwa, D.L. (2018) SWOT Analysis for Developing Dry Ports in Togo. American Journal of Industrial and Business Management, 8, 1407-1417.

https://doi.org/10.4236/ajibm.2018.86094

Received: May 17, 2018

Accepted: June 2, 2018

Published: June 5, 2018

Copyright ( 92018 by authors and Scientific Research Publishing Inc. This work is licensed under the Creative Commons Attribution International License (CC BY 4.0).

http://creativecommons.org/licenses/by/4.0/

(c) (i) Open Access

\begin{abstract}
Dry ports currently play an integral role in the global logistics network relieving seaport from congestions and enabling more efficient and effective cargo handling with improved logistics solutions to facilitate cargo transportation for shippers in the port's hinterland locations. This paper focuses on developing dry ports in Togo and the concept of dry port as well as the drivers behind the emergence and development of dry ports has been extensively reviewed in existing literatures. It also delves into the classification of dry ports based on the geographical factors relating to distance from the seaport. In addition, Port of Lomé is presented as a main gateway port for West African Landlocked Countries (LLC's) with major focus on Lomé-Ouagadougou CU9 transit corridor, which remains a pivot channel for transporting merchandise designated for hinterland markets. Finally, SWOT analysis methodology was applied to analyze the endogenous and exogenous factors that are considered vital for developing dry ports in Togo followed by conclusion for future implementation.
\end{abstract}

\section{Keywords}

SWOT, Dry Ports, Port of Lomé, West Africa, Transit Traffic

\section{Introduction}

Togo is among the fast growing emerging economies in West Africa but is currently being encumbered with an underdeveloped and inefficient land transport infrastructure that has not kept pace with rising demand as it continues to pursue its economic growth. Its road network, which carries almost $80 \%$ of the country's passenger traffic, remains highly congested [1]. Additionally, Container Terminal Capacity (CTC) has become a major problem nowadays in many 
ports around the globe due to the remarkable growth of globalization and container transportation. [2] ascertained that in order to have efficient and effective container terminal management, new solutions should be established. Considering the growth in the number of containers and vessel dimensions, there is bound to be pressure on seaports to increase the capacity of their container terminals either by new buildings or adding more infrastructure facilities [3]. In this context, the reinforcement of Togo's container port and in particular its dry port sector represents an essential effort to overcome the high logistics costs which renders it imports and exports uncompetitive. Therefore, developing dry port(s) to relieve the port of Lomé would definitely be a proactive measure to be implemented by its stakeholders.

\subsection{Dry Port Concept}

The concept of dry ports became global in conjunction with containerization. Dry Port or Inland Clearance Depot (ICD) can be defined as: "A common user facility with public authority status, equipped with fixed installations and offering services for handling and temporary storage of any kind of goods (including containers) carried under customs transit by any applicable mode of transport, placed under customs control and with customs and other agencies competent to clear goods for home use, warehousing, temporary admissions, re-export, temporary storage for onward transit and outright export." [4]

\subsection{Drivers behind the Emergence and Development of Dry Ports}

The utilization of inland transport networks is becoming more pragmatic [5] since every business entity has its own peculiar reasons for developing dry ports. The main drivers behind the emergence and development of dry ports are: seaport constraints, hinterland access and economic zone facilitation. Numerous gateway ports are faced with several development constraints and the most common issues are land availability, environmental problems and diseconomies of scale as congestion. Regarding these constraints, many seaport authorities have established dry ports as a solution to relieve encumbrances and improve efficiency through a modal split by relocating space-consuming activities to satellite locations. An example of this is the port of Genoa [6].

\subsection{Classification of Dry Port}

The location of a Dry Port depends on the needs, assessment criteria and a center of gravity beneficial to the shippers. Nonetheless, the evaluation of Dry Port implementation should be assessed not only with the cost factors but also with added values that can be provided by a dry port to customers and logistics channels. Remarkable researches on dry port distances have been conducted by [7] [8] [9]. According to these authors, dry ports can be divided into close, mid-range and distant Dry Ports as shown in (Table 1) and the distance of each dry port has a significant impact on it functions. 
Table 1. Interdependence between Dry Port Classification Schemes.

\begin{tabular}{ccc}
\hline Configuration & Distance from Sea-Port & Main Function \\
\hline Close Dry Port & $<50 \mathrm{~km}$ & Satellite Terminal \\
Mid-Range Dry Port & $\geq 50 \mathrm{~km} ; \leq 500 \mathrm{~km}$ & Load Center \\
Distance Dry Port & $500>$ & Transshipment \\
\hline
\end{tabular}

Source: S. Islam et al. [2013]. Factors affecting seaport capacity: Managerial implications for a simulation framework.

1) Close dry ports or satellite terminals: These dry ports are sited in proximity to seaports with robust connections by rail, tucks and or barges and are mostly developed as extensions of a maritime seaport. The main function of such dry ports is to relieve the seaports from the burdens such as congestions, environmental problems or space shortage. Furthermore, such dry ports also perform similar administrative functions as the seaports.

2) Mid-range dry ports: These types of dry port function as intermodal centers to consolidate or deconsolidate cargoes and can also work as a modal shift hub before the cargo reaches its destination. Seaports benefits from this types of dry port by increasing their hinterland access and getting closer to the shippers.

3) The distant dry port: These types of dry ports are sited in a proximity to the market, which might be the consumption location in import-based supply chain network, or an essential manufacturing location in export-based supply chain network. Such dry port functions imperatively in the logistics system of landlocked countries to connect the global markets.

In a close dry port configuration, the dry ports are sited at short distance $\leq 50$ $\mathrm{km}$ from a seaport and they function as consolidation centers between shippers located on the outskirts of the urban areas and the seaport. Considering the short distance, it offers container buffering services and also conducts a structural shuttle services to synchronize with cargo operations process at the seaport.

Middle range dry ports located between a distance of $\geq 50 \mathrm{~km}$ and $\leq 500 \mathrm{~km}$ as indicated in Table 1. These dry ports mainly functions as load centers between the seaport and the shippers in inland location in configured transport chain network.

The distance dry ports are usually sited in the hinterland locations and are far from the seaports. They function as load centers and multimodal logistics platforms serving as hubs for coordinating logistics integration process to enhance an efficient freight distribution.

\section{Port of Lomé, a Gateway to West African Landlocked Countries}

The port of Lomé lies by the (Atlantic Coast) $06^{\circ} 8^{\prime} \mathrm{N}$ and $01^{\circ} 17^{\prime} \mathrm{E}$ at the extreme southwestern corner of the nation and it is the state's major economic engine handling over $80 \%$ of Togo's seaborne trade (Figure 1). In 2017 the port handles about 19.0 million tons of cargo (Figure 2) of which over 2.6 million are transit 


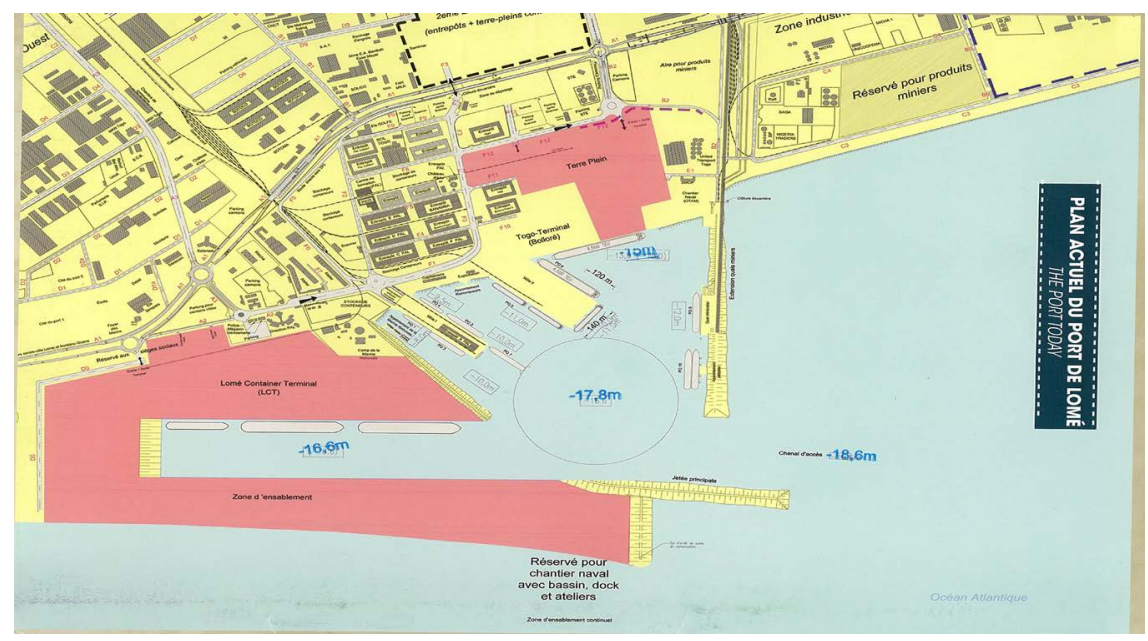

Figure 1. Satellite image of the port of Lomé. Source:

http://www.togo-port.net/index.php?option=com_content\&view=article\&id=134\&Itemid $=116$.

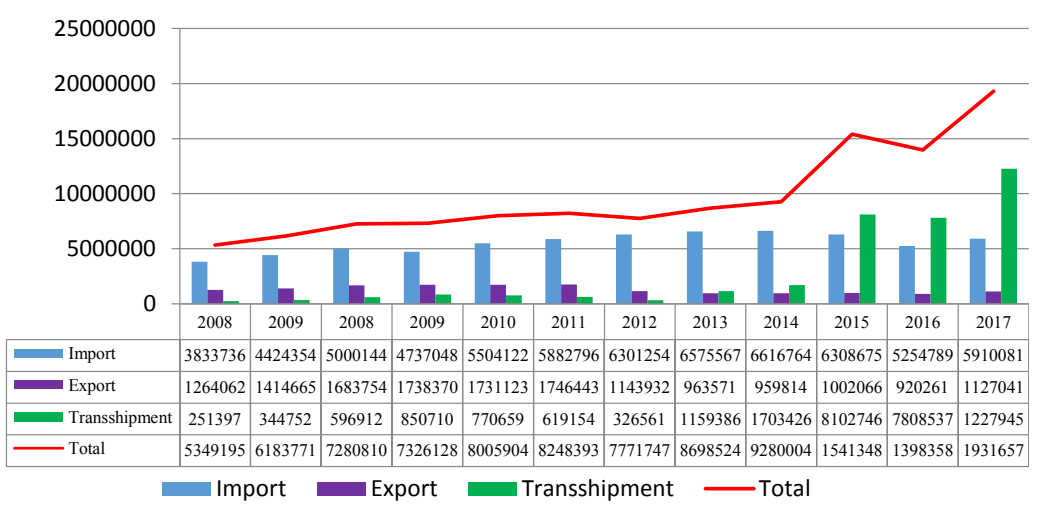

Figure 2. Port of Lomé Global Traffic Statistics for 12 years 2006-2017. Source: Author's compilation from:

http://www.togo-port.net/index.php?option=com_content\&view=article\&id=203\&Itemid $=152$.

traffic with main destination to landlocked countries such as Burkina-Faso, Mali, Niger and other neighboring West African states (Figure 3). Major cargoes transported via the port of Lomé include; refined petroleum products, Cotton, Rice, Fertilizer, used Vehicles, Textiles etc. (Table 2). The port of Lomé's quay measures over 1720 meters allowing it to accommodate between 8 and 10 ships at a time and it has over twelve (12) ship-to-shore container cranes with the capacity of 40 tons each. Presently, the port of Lomé consists of Pier 1, Pier 2, Oil Terminal, Ore terminal and a fishing harbor with a very low tide of $(1.20 \mathrm{~m})$ and moderate wind [10].

The port of Lomé owns a warehouse storage capacity area of $115,000 \mathrm{~m}^{2}$ and $200,000 \mathrm{~m}^{2}$ open storage for containers, 600,000 $\mathrm{m}^{2}$ parking lot for used imported vehicles while other designated areas mainly for port operations. Cargo handling operation in the port of Lomé is undertaken by both the port authorities 
Table 2. Major cargoes transported via Port of Lomé to West African LLCs.

\begin{tabular}{|c|c|c|}
\hline \multirow[t]{2}{*}{ Togo \& W/A LLCs } & \multicolumn{2}{|c|}{ Port of Lomé } \\
\hline & Import (Northbound) & Export (Southbound) \\
\hline Togo & $\begin{array}{l}\text { Refined petroleum, Vehicles, Textiles, } \\
\text { Rice, Fertilizers, Donation from WFP }\end{array}$ & $\begin{array}{c}\text { Phosphate, Marble, Raw Cotton, } \\
\text { Cement, Clinker }\end{array}$ \\
\hline Burkina-Faso & $\begin{array}{l}\text { Rice, Refined petroleum, Vehicles, } \\
\text { Fertilizers, Sugar, White Cement, Textiles } \\
\text { \& Donation from WFP }\end{array}$ & $\begin{array}{l}\text { Gold, Raw Cotton, Sesames } \\
\text { seeds, Coconut, Groundnut }\end{array}$ \\
\hline Mali & $\begin{array}{l}\text { Wheat, Refined petroleum, Medications, } \\
\text { Vehicles, Textiles \& Donations from WFP }\end{array}$ & $\begin{array}{c}\text { Cashew nuts, Scrap Metals, Se- } \\
\text { sames seeds }\end{array}$ \\
\hline Niger & $\begin{array}{c}\text { Vehicles, Cement, Medications, Rice, } \\
\text { Textile, Vegetable oil, }{ }^{1} \text { Donations from } \\
\text { WFP. }\end{array}$ & $\begin{array}{l}\text { Uranium products, Radio-active, } \\
\text { chemicals, Onion, Potassium }\end{array}$ \\
\hline
\end{tabular}

Source: Author's compilations from the representatives of Burkina-Faso Chamber of Commerce (CBC), Union of Malian Warehouse (EMATO) \& Port of Lomé statistics bureau in Togo (2018).

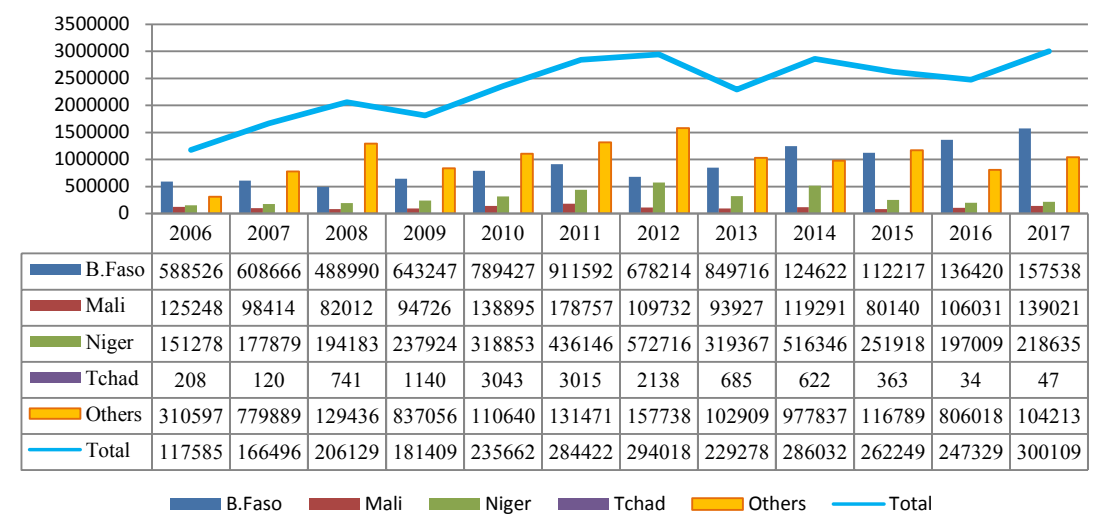

Figure 3. Port of Lomé Transit Traffic Statistics for 12 years 2006-2017. Source: Author's Compilation from:

http://www.togo-port.net/index.php?option=com_content\&view=article\&id=134\&Itemid $=116$.

and private companies. The Port authority plays a principal role in handling of clinker, wheat, hydrocarbons and coasters. Container handling is performed by Société d' Entreprise de Manutention Maritime (SE2M) while conventional cargo handling is carried out by Société d' Entreprise de Moyens et de Manutention Maritime (SE3M). SE2M and SE3M are subsidiaries of Bolloré Africa Logistics group while Manuport is a subsidiary of Necotrans group. Major operators in the port comprises of; Togo Terminal (container terminal operator), Lomé Multipurpose Terminal (conventional terminal operator), SDV Togo (Shipping and transit agency), SAGA Togo (shipping and transit agency), STCM (Shipping agency), GETMA and MSC, (shipping companies) and SDV-Damco (forwarding agent) [10]. Additionally, the port of Lomé is currently experiencing a significant increase in its annual throughput (Figure 2) as well as transit traffic (Figure 3) ${ }^{1}$ Donations from WFP are cargoes supplied by the United Nations World Food Program to support Least Developing Countries (LCD's). 
in the region thus; this has provided it with the leeway of becoming a pivot gateway port to West African hinterland countries.

\section{SWOT Analysis}

SWOT analysis is a common business analytic tool used by many organizations to assess their services/products and market environment when deciding the best way to achieve a continuous future growth. In the academic context, several scholars have also applied the SWOT analysis as a pivot tool in their works. For example; [7] applied the SWOT analysis in developing dry port in Vietnam, [11] also combine SWOT-PEST analysis in assessing China's dry port system. Additionally, SWOT analysis was applied in conducting a comparative study of dry port in the United Kingdom and Nigeria by [12] while [9] also employed SWOT techniques in the development of dry ports in Wuyishan.

\section{SWOT Analysis \& Strategic Planning}

SWOT analysis and strategic planning is a structural technique to maintain thebalance between an organization and its external environment for swift operational procedures over time. Thus, SWOT analysis remains a pilot analytic tool that set stages for decision making techniques.

Step I: This stage involves the collection and appraisal of prime data regarding the nature of the organization and the purpose of collected data. Once these data are collated and appraised, the organizations competencies in this field are also evaluated.

Step II: In this stage, data on the prime organization are collated and classified into four sets: Strengths, Weaknesses, Opportunities and Threats. The Strengths and Weaknesses are generally considered as elements within the organization while Opportunities and Threats basically arise from exogenous factors.

Step III: This stage requires the development of a SWOT matrix for each organizational alternative under review, and its purpose is to ensure a correlation between the selected alternatives and the organizational objective.

Step IV: This includes integrating the SWOT analysis reviewed into the decision making procedure in order to ascertain which corporate alternatives best meet the organization inclusive strategic objectives.

The implementation of Togo's dry port project must be a systematic strategy that can stimulate, develop and sustain the transit traffic through Lomé-Ouagadougou transit corridor to the hinterland markets. Therefore, this strategy is well strengthened in the aspect of the corridor's Strengths, Weaknesses, Opportunities and Threats as indicated in (Figure 4).

\section{Strengths}

1) Strategic Geographical Location as a Gateway Port for West African LLC's:

Togo's geographical location in the region makes its seaport and corridor accessible in relations of distance to the three West African hinterland countries 


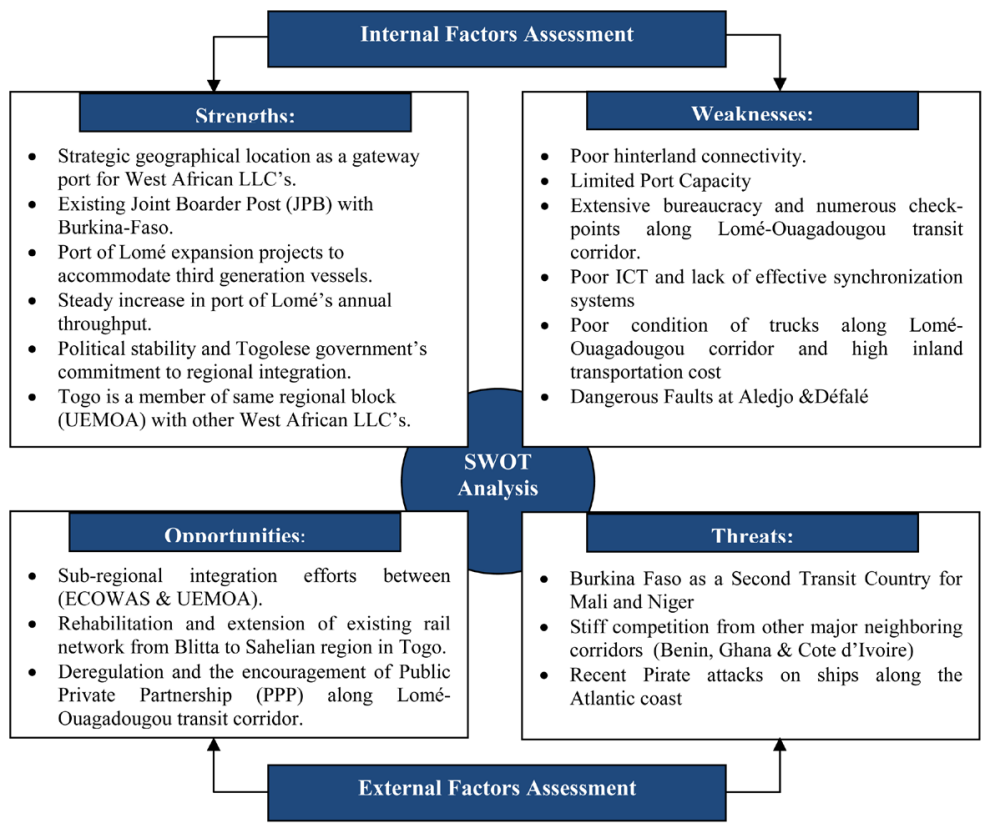

Figure 4. SWOT Analysis Model. Source: Author (2018).

(Burkina Faso, Mali and Niger). For example, the distances from the port of Lomé to the capital city of the LLCs are $986 \mathrm{~km}$ (Ouagadougou), 11,973 km (Bamako) and $1222 \mathrm{~km}$ (Niger) respectively. This marginal variance in the distances from the port of Lomé to the LLC's destinations shows how tactically located Togo has been for transit traffic flow to its landlocked neighbors.

\section{2) Existing Joint Boarder Post (JPB) with Burkina-Faso:}

Togo has established the first regional Joint Boarder Post (JPB) with Burkina-Faso at Cinkassé along Lomé-Ouagadougou transit corridor. The JBP is operational but the customs systems on either side of the border are currently being assessed in order to harmonize and simplify the border clearance between both countries as well as enhance the flow of transit traffic via the corridor.

3) Port of Lomé Expansion Projects to Accommodate $3^{\text {rd }}$ Generation Vessels:

At present, significant development projects are ongoing in the port Lomé by Bolloré Africa Logistics with an objective of making the port a transshipment hub in the sub-region, combined with the short to medium term projects aimed at putting the port as a highly efficient maritime gateway to West Africa. For example, the fourth phase of the Lomé Container Terminal (LCT) is currently undergoing extension work and these facilities are projected to be ready by 2019 .

4) Steady Increase in Port of Lomé's Annual Throughput and Transit Traffic:

Since the inauguration of the new Lomé Container Terminal (LCT) on the $14^{\text {th }}$ October 2014, the port of Lomé has experienced a significant increase in its annual throughput from 9.2 million to 19.3 million in 2017 and this has also contributed to the increase in transit traffic via Lomé-Ouagadougou transit corridor [10]. 
5) Political stability and Togolese government's commitment to regional integration:

Within the West African sub region, Togo has been known as one of the peaceful nation along the coast thus encouraging investors and transit shipper's confidence through the Lomé-Ouagadougou transit corridor. Furthermore, Togo is also at the vanguard of regional initiatives aimed at stimulating regional integration and trade. In this regards, its political climate is satisfactory regarding intraregional trade with hinterland countries.

6) Togo is a member of same regional block (UEMOA) with other West African LLC's

Another major strength is that Togo and the three West African hinterland countries (Burkina-Faso, Mali and Niger) belongs to the West African Economic Monetary Union which is a regional block for all the francophone countries located within the sub-region. Furthermore, they share the same official language as well as currency unit (francs $C F A$ ).

\subsection{Weaknesses}

\section{1) Poor hinterland connectivity:}

The Lomé-Ouagadougou CU9 corridor is a major intermodal transit corridor in W/A and as well as the spine of Togo's road network linking all the regions in the country but the absence of an alternative mode of transport is mounting a significant pressure on the road network therefore leading to constant damage and repairs which in long run turns out to be death traps to commuters.

\section{2) Limited port capacity:}

Due to the steady increase in the throughput at the port of Lomé, there is an acute shortage of container stacking area and trucks parking lot therefore, most trucks are forced to park along the road forming long queues in order to access the port and this in long run impedes the flow of normal traffic along the national route (N2) popularly known as Abidjan-Lagos corridor.

3) Extensive bureaucratic and documentation procedures and numerous check-points along Lomé-Ouagadougou transit corridor:

The Lomé-Ouagadougou transit corridor is one of the busiest in the sub-region transporting merchandise to hinterland countries but a major impediment on this route is its lengthy customs procedure at the port as well as multiple check-points along the corridor thus, increasing the cost and time transporting merchandise along the corridor.

\section{4) Poor ICT and lack of effective synchronization systems:}

The port of Lomé, terminal du Sahel and the Joint Border Post (JPB) at Cinkassé lacks an efficient and effective information and communication technology platform for data exchange and synchronization. Most documents are manually processed and the few electronic systems available are usually shut down due to unavailability of internet access.

\section{5) Poor Condition of Trucks along the Corridor}

The poor condition of trucks via the corridor is likewise a major factor stated 
by shippers along the corridor. According to the statistical information, more than seventy (70\%) of the trucks operating along the Lomé-Ouagadougou transit corridor are within the mean age of (10 - 25 years). Reason being that these trucks are usually imported as second-hand vehicles mostly but are currently in service along the corridor. Therefore, they are always engaged in mechanical faults during transit and this also contributes to the undue delay in transit time.

6) Dangerous Faults at Aledjo \& Défalé

Dangerous Fault at Aledjo \& Défalé: The topography of some parts of Lomé-Ouagadougou transit corridor is noted to be impeding factors to the flow of transit traffic along the corridor. The landscape varies considerably with a long flat stretch contrast of more than $300 \mathrm{~km}$ of hilly geography in Togo beginning from Tsétvie to Sokodé, culminating in $75 \mathrm{~km}$ of steep road between Sokodé and Kara and $32 \mathrm{~km}$ sharp and sloppy mountainous section between Niamtougou and Mango. These locations are considered as dangerous spots and as likewise serving as bottlenecks along the corridor.

\subsection{Opportunities}

1) Sub-regional integration efforts between (ECOWAS \& UEMOA) to enhance effective transit traffic policy and regulations:

These regional organizations have enacted quite sustainable program to enhance intra-regional transit traffic through the improvement of road frameworks, the universalization and synchronization of customs procedures and documentation systems, the institution of joint border control points between countries as well as road transport policies concerning vehicle and driver licensing, axle load limitations and insurance etc. There are currently strengthened efforts to guarantee full enactment of these policies by member countries and this will go a long way to create golden chances for transit traffic in Togo.

2) Rehabilitation and extension of existing rail network from Blitta to Sahelian region in Togo

Togo currently own an existing rail network from Lomé to Blitta in the central part of the country thus, the rehabilitation and extension of this network to the border between Burkina-Faso at Cinkassé and beyond, would enable a balanced and complementary development of road and railway transport subsectors as well as reduce the rate of road accidents along Lomé-Ouagadougou transit corridor.

3) Deregulation and the encouragement of Public Private Partnership (PPP):

A strategic plan to implement and develop dry ports in Togo is through deregulation of policies and privatization of the port industry. Most sectors in the Togolese economy are controlled by the state government which intends to monopolize the operational procedures of the port system in Togo.

\subsection{Threats}

1) Burkina Faso as a Second Transit Country for Mali and Niger: 
Burkina-Faso also remains a great bottleneck in the system for shippers in Mali and Niger using Lomé-Ouagadougou transit corridor. This is because the Customs procedures on Burkina-Faso territory are cumbersome thus creating a productive ground for undue delay of trucks and extortion of illegal fees by security forces from transporters.

2) Stiff competition from other major neighboring corridors (Benin, Ghana, Cote d'Ivoire, Senegal and Nigeria):

Competing corridors such as Abidjan-Ouagadougou, Cotonou-Niamey, Tema-Ouagadougou, Dakar-Bamako \& Lagos-Niamey are also striving continuously in order to gain a larger market share of the transit traffic. For Example; Abidjan-Ouagadougou is known to be a principal channel for transit traffic to West African LLC's especially (Burkina-Faso and Mali) with a good road/rail connection. Apart from Ghana and Nigeria, other competing corridors also shares common currency and official language with the LLCs.

3) Recent Pirate Attacks on Ships along the Gulf of Guinea:

Recent pirate attacks on the gulf of guinea might also discourage major shipping line from calling at West African ports. According to the International Maritime Bureau [13], countries affected mostly in West Africa includes; Benin, Ghana, Nigeria and Togo with 11 attacks in the first quarter of 2013.

\section{Conclusion}

Cumulative concerns about the increase in demand of dry ports in West Africa remain a pilot topic for most port authorities within the region. Transport cost continues to increase at tremendous rate with lengthy lead time along various West African corridors. Most ports have embark on vast port expansion projects competing for a regional hub port but essential steps are not being implemented regarding the developing or rehabilitations of infrastructures linking the hinterland markets. The port of Lomé has also experienced a rapid development in port infrastructure in recent years due to concession with Bolloré Africa Logistics and this is coupled with the steadfast growth within West African economy giving rise to an increase in demand for transport services. Therefore, the development of dry ports as well as rehabilitation of existing transport infrastructures would become a strategic pilot program to promoting regional trade in Togo and Sub-Saharan Africa. A cost benefit analysis also needs to be carefully evaluated and discussed among the various stakeholders in Togo because dry ports are developed in a complex system where other immediate supporting infrastructures such as road, railways are already in place with maintenance measures, regulatory systems and institutional framework properly designed to optimize the participation of public and private sector. Finally, the port of Lomé has envisaged priding itself as a hub port in West Africa due to its enormous expansion projects and short corridor distance. Therefore, there is a need for the port authority and other stakeholders to implement strategic measures that will enhance its sustainability as well as minimizing the transportation cost along the 
CU9 corridor so as to promote regional trade in West Africa.

\section{References}

[1] DANIDA-Saana Consulting. (2015) Accelerating Trade in West Africa-ATWA.

[2] Islam, S. and Olsen, T.L. (2013) Factors Affecting Seaport Capacity: Managerial Implications for a Simulation Framework. https://www.asor.org.au/conferences/asor2013/J3/islam.pdf

[3] Rosso, V., Woxenius, J. and Olandersson, G. (2006) Organization of Swedish Dry Ports.

https://www.gu.se/digitalAssets/1344/1344736_2006_meddelande_123_-_sustaccess -_ddry_ports_in_sweden.pdf

[4] UNESCAP (2012) Introduction to the Development of Dry Ports in Asia. http://www.unescap.org/sites/default/files/Intro-dry-ports.pdf

[5] Veenstra, A., Zuidwijk, R. and Asperen, E. (2012) The Extended Gate Concept of Container Terminals: Expanding the Notion of Dry Ports. Maritime Economics \& Logistics, 14, 14-32. https://doi.org/10.1057/mel.2011.15

[6] Caballini, C. and Gattorna, E. (2009) The Expansion of the Port of Genoa: The Rivalta Scrivia Dry Port. Transport and Communications Bulletin for Asia and the Pacific, 78, 103-125.

[7] Nguyen, C.L. and Notteboom, T. (2016) Dry Ports as Extensions of Maritime Deep-Sea Ports: A Case Study of Vietnam. https://biblio.ugent.be/publication/8042448/file/8042449.pdf

[8] Roso, V. (2005) The Dry Port Concept Applications in Sweden. Proceedings of Logistics Research Network, Plymouth, International Logistics and Supply Chain Management.

[9] Wang, M.J. (2011) Analysis of SWOT for the Development of Dry Port in Wuyishan. Journal of Wuyi University, 4, No. 013.

[10] Port of Lomé. http://www.togo-port.net/

[11] Chen, J.H. and Wang, Y. (2002) SWOT-PEST Analysis in China's Dry Port. Advance Materials Research, 479, 1004-1012.

[12] Garnwa, P., Baredford, A. and Pettit, S. (2009) Dry Ports: A Comparative Study of the United Kingdom and Nigeria. Transport and Communications Bulletin for Asia and the Pacific. No. 78: Development of Dry Ports, New York, UNESCAP.

[13] International Maritime Bureau. (2015) Piracy and Armed Robbery against Ships. 